Supporting Information

\title{
Biocidal Activity and Mechanism Study of Unsymmetric Oligo-phenylene-ethynylenes
}

\author{
Wei Liao,,2, Lian-gang Zhuo 1,2,3, Xia Yang 1,2,3, Peng Zhao',2, Wentao Kan ${ }^{1,2}$, \\ Guanquan Wang 1,2, Hu Song 1,2, Hongyuan Wei,1,2,3, Yuchuan Yang 1,2,3, \\ Guozhong Tian', Rongtao Zhao, Zhijun Zhou',6, and Jing Wang ${ }^{1,2 *}$
}

${ }^{1}$ Institute of Nuclear Physics and Chemistry (INPC), China Academy of Engineering Physics (CAEP), Mianyang, 621999, P. R. China

${ }^{2}$ Key Laboratory of Nuclear Medicine and Molecular Imaging of Sichuan Province, Mianyang, 621999, P. R. China

${ }^{3}$ Collaborative Innovation Center of Radiation Medicine of Jiangsu, Higher Education Institutions, Suzhou, 215123, P. R. China

${ }^{4}$ National Institute for Communicable Disease Control and Prevention, Chinese Center for Disease Control and Prevention, Beijing, 102206, P. R. China

${ }^{5}$ PLA Center for Disease Control and Prevention, Beijing, 100071, P. R. China

${ }^{6}$ Department of Nuclear Medicine, The Affiliated Hospital of Southwest Medical University, Luzhou, Sichuan 646000, People's Republic of China 
Corresponding Author

* Phone: (86)816-2485484

E-Mail: wangjing_es@caep.cn 


\section{Contents}

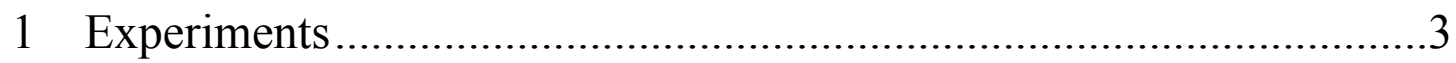

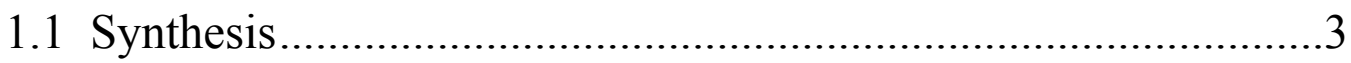

1.2 Bacterial Growth Conditions ...................................................14

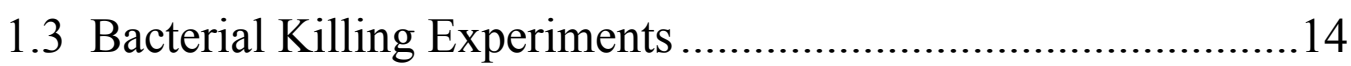

1.4 Preparation of Fluorescein-Loaded Vesicles and Vesicle

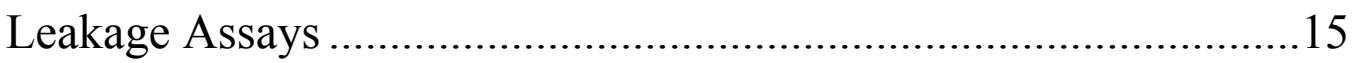

1.5 Reactive oxygen species(ROS) measurements .........................16

1.6 Observation of Cell Morphology ...............................................17

1.7 Confocal laser scanning microscopy (CLSM) characterization 17

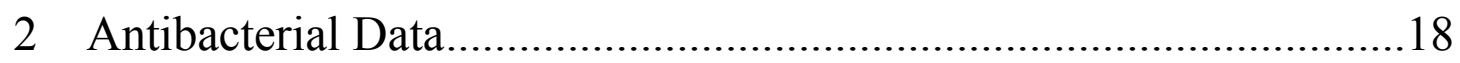

3 Emission spectra of light source .......................................................23

4 Image of $E$. coli stained by DAPI and FITC .....................................25 


\section{Experiments}

\subsection{Synthesis}
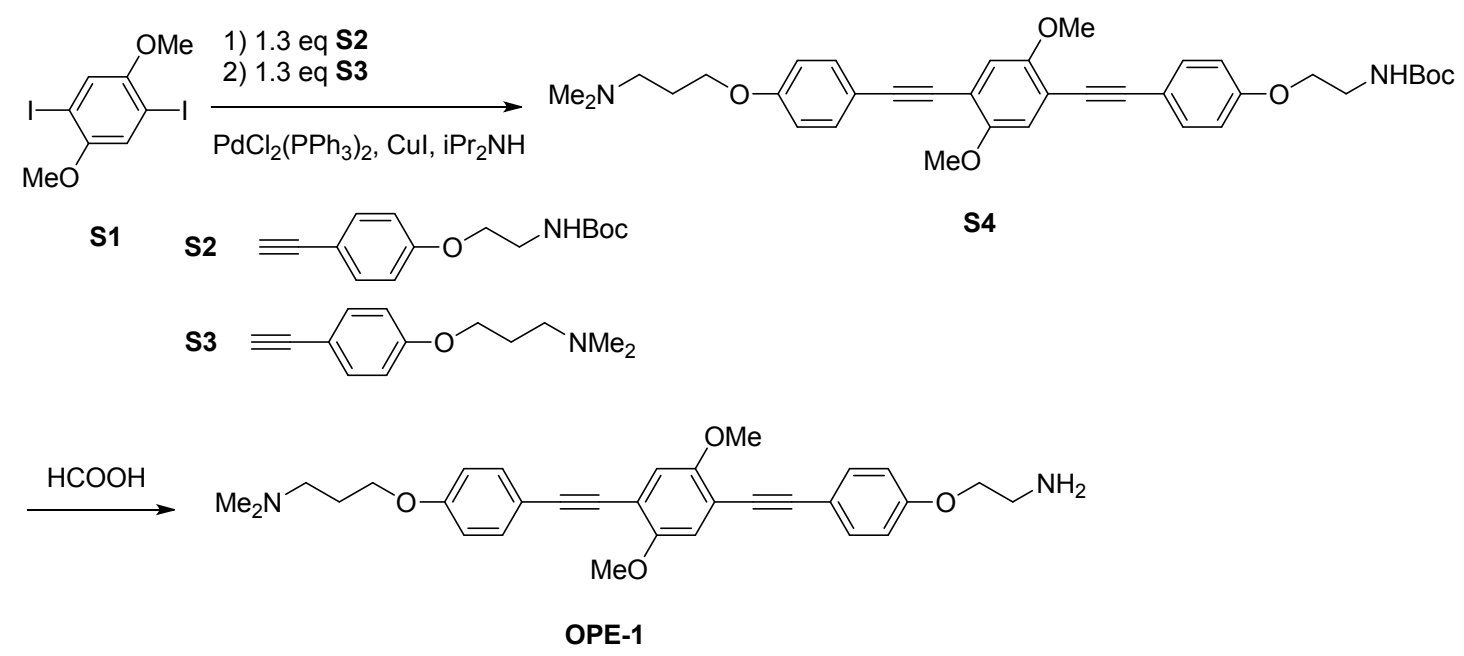

Compound S4. Compound S1 (0.3059 g, $0.78 \mathrm{mmol})$, Compound S2 (0.2640 g, $1.01 \mathrm{mmol}), \mathrm{Pd}\left(\mathrm{PPh}_{3}\right) \mathrm{Cl}_{2}(0.0274 \mathrm{~g}, 0.039 \mathrm{mmol}), \mathrm{CuI}(0.0149$ $\mathrm{g}, \quad 0.078 \mathrm{mmol}$ ) and $6 \mathrm{~mL}$ THF were mixed and degassed by purging with argon gas for 5 minutes, then diisopropylamine $(0.3939 \mathrm{~g}, \quad 3.9$ mmol) was added via a injector. After the mixture was stirred for 12 hours, compound $\mathbf{S 3}(0.2053 \mathrm{~g}, 1.01 \mathrm{mmol})$ was added, then reaction mixture was stirred for another 12 hours. The mixture was concentrated and the residue was purified by flash column chromatography with silica gel which was washed by solution of $\mathrm{MeOH}$ and $\mathrm{CH}_{2} \mathrm{Cl}_{2}$ to afford yellow solid S7, (0.1855 g, $0.31 \mathrm{mmol})$, yield 40\%.

Compound OPE-1. Compound $\mathbf{S} 7(0.1855 \mathrm{~g}, 0.31 \mathrm{mmol})$ was added to 1 
$\mathrm{mL}$ formic acid and stirred at room temperature for 12 hours. The mixture was concentrated and the residue was added $20 \mathrm{~mL} 1 \mathrm{~mol} / \mathrm{L} \mathrm{NaOH}$ solution. Extraction of solution three times using $\mathrm{CH}_{2} \mathrm{Cl}_{2}$ and the $\mathrm{CH}_{2} \mathrm{Cl}_{2}$ solution was washed by $1 \mathrm{~mol} / \mathrm{L} \mathrm{NaOH}$ solution, water, saturated $\mathrm{NaCl}$ solution successively and dried by anhydrous $\mathrm{NaSO}_{4}$ for 4 hours. Removing the $\mathrm{NaSO}_{4}$ through filtration, the organic phase was concentrated to afford yellow solid OPE-1 (0.1246 g, $0.25 \mathrm{mmol})$, yield 81\%. ${ }^{1} \mathrm{H}$ NMR (400 MHz, DMSO) $\delta 7.50-7.43(\mathrm{~m}, 4 \mathrm{H}), 7.13(\mathrm{~s}, 2 \mathrm{H})$, $7.02-6.94(\mathrm{~m}, 4 \mathrm{H}), 4.03(\mathrm{t}, \mathrm{J}=6.4 \mathrm{~Hz}, 2 \mathrm{H}), 3.97(\mathrm{~s}, 2 \mathrm{H}), 3.83(\mathrm{~s}, 6 \mathrm{H})$, $2.90(\mathrm{~s}, 2 \mathrm{H}), 2.35(\mathrm{t}, \mathrm{J}=7.0 \mathrm{~Hz}, 2 \mathrm{H}), 2.14(\mathrm{~s}, 6 \mathrm{H}), 1.90-1.81(\mathrm{~m}, 2 \mathrm{H})$.

${ }^{13} \mathrm{C}$ NMR (101 MHz, DMSO) $\delta 159.04,158.99,153.28,132.85,132.03$, $131.51,131.41,128.80,128.68,115.30,114.89,114.85,114.24,112.55$, 94.78, 84.71, 65.95, 56.17, 55.56, 45.19, 26.79, 0.08. HRMS[ESI]: calcd for $\mathrm{C}_{31} \mathrm{H}_{35} \mathrm{~N}_{2} \mathrm{O}_{4}(\mathrm{M}+\mathrm{H})^{+}$, 499.2591; found, 499.2576.

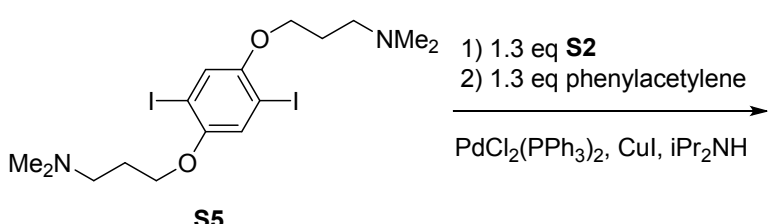

S5

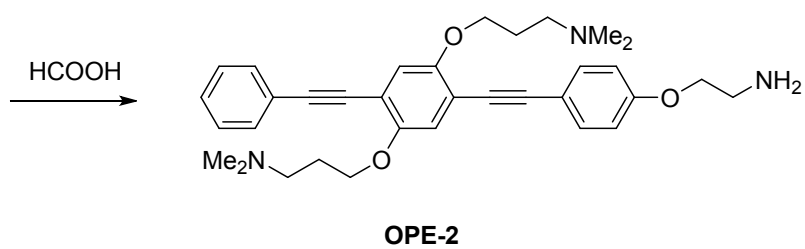

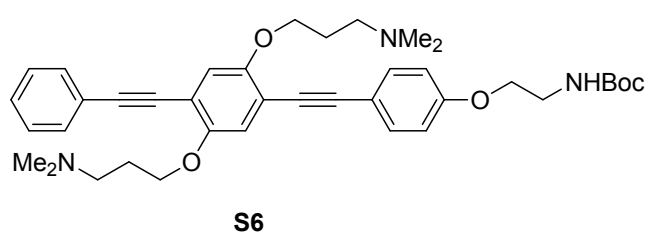

S6 
Compound S6. Compound S5 (0.3094 g, 0.58 mmol), Compound S2 (0.1960 g, $0.75 \mathrm{mmol}), \mathrm{Pd}\left(\mathrm{PPh}_{3}\right) \mathrm{Cl}_{2}(0.0204 \mathrm{~g}, 0.029 \mathrm{mmol}), \mathrm{CuI}(0.0110$ g, $0.058 \mathrm{mmol}$ ) and $6 \mathrm{~mL}$ THF were mixed and degassed by purging with argon gas for 5 minutes, then diisopropylamine $(0.2929 \mathrm{~g}, 2.9 \mathrm{mmol})$ was added via a injector. After the mixture was stirred for 12 hours, phenylacetylene $(0.0766 \mathrm{~g}, 0.75 \mathrm{mmol})$ was added, then reaction mixture was stirred for another 12 hours. The mixture was concentrated and the residue was purified by flash column chromatography with silica gel which was washed by solution of $\mathrm{MeOH}$ and $\mathrm{CH}_{2} \mathrm{Cl}_{2}$ to afford yellow solid S6, (0.0423 g, $0.066 \mathrm{mmol})$, yield 11\%.

Compound OPE-2. Compound S6 (0.0423 g, $0.066 \mathrm{mmol})$ was added to $1 \mathrm{~mL}$ formic acid and stirred at room temperature for 12 hours. The mixture was concentrated and the residue was added $20 \mathrm{~mL} 1 \mathrm{~mol} / \mathrm{L}$ $\mathrm{NaOH}$ solution. Extraction of solution three times using $\mathrm{CH}_{2} \mathrm{Cl}_{2}$ and the $\mathrm{CH}_{2} \mathrm{Cl}_{2}$ solution was washed by $1 \mathrm{~mol} / \mathrm{L} \mathrm{NaOH}$ solution, water, saturated $\mathrm{NaCl}$ solution successively and dried by anhydrous $\mathrm{NaSO}_{4}$ for 4 hours. Removing the $\mathrm{NaSO}_{4}$ through filtration, the organic phase was concentrated to afford yellow solid OPE-2 (0.0303 g, $0.056 \mathrm{mmol})$, yield 85\%. ${ }^{1} \mathrm{H}$ NMR (400 MHz, DMSO) $\delta 7.55-7.50$ (m, 2H), $7.49-7.40$ (m, 6H), $7.15(\mathrm{~s}, 1 \mathrm{H}), 7.13(\mathrm{~s}, 1 \mathrm{H}), 7.03-7.01(\mathrm{~m}, 1 \mathrm{H}), 7.01-6.98(\mathrm{~m}, 1 \mathrm{H})$, $4.07(\mathrm{t}, \mathrm{J}=5.7 \mathrm{~Hz}, 4 \mathrm{H}), 3.98(\mathrm{t}, \mathrm{J}=5.7 \mathrm{~Hz}, 2 \mathrm{H}), 2.90(\mathrm{t}, \mathrm{J}=5.7 \mathrm{~Hz}, 2 \mathrm{H})$, $2.43(\mathrm{t}, \mathrm{J}=7.1 \mathrm{~Hz}, 4 \mathrm{H}), 2.14(\mathrm{~s}, 6 \mathrm{H}), 2.13(\mathrm{~s}, 6 \mathrm{H}), 2.05-1.93(\mathrm{~m}, 2 \mathrm{H})$, 
$1.91-1.83(\mathrm{~m}, 4 \mathrm{H})$. HRMS[ESI]: calcd for $\mathrm{C}_{31} \mathrm{H}_{35} \mathrm{~N}_{2} \mathrm{O}_{4}(\mathrm{M}+\mathrm{H})^{+}$, 499.2591; found, 499.2576. ${ }^{13} \mathrm{C}$ NMR (101 MHz, DMSO) $\delta$ 159.01, $153.11,152.87,132.75,131.12,128.79,122.55,116.52,116.37,114.95$, $114.40,113.71,112.64,94.94,94.47,86.11,84.69,69.94,67.14,55.68$, 45.22, 26.99. HRMS[ESI]: calcd for $\mathrm{C}_{34} \mathrm{H}_{41} \mathrm{~N}_{3} \mathrm{O}_{3}(\mathrm{M}+\mathrm{H})^{+}$, 540.3221; found, 540.3172 .
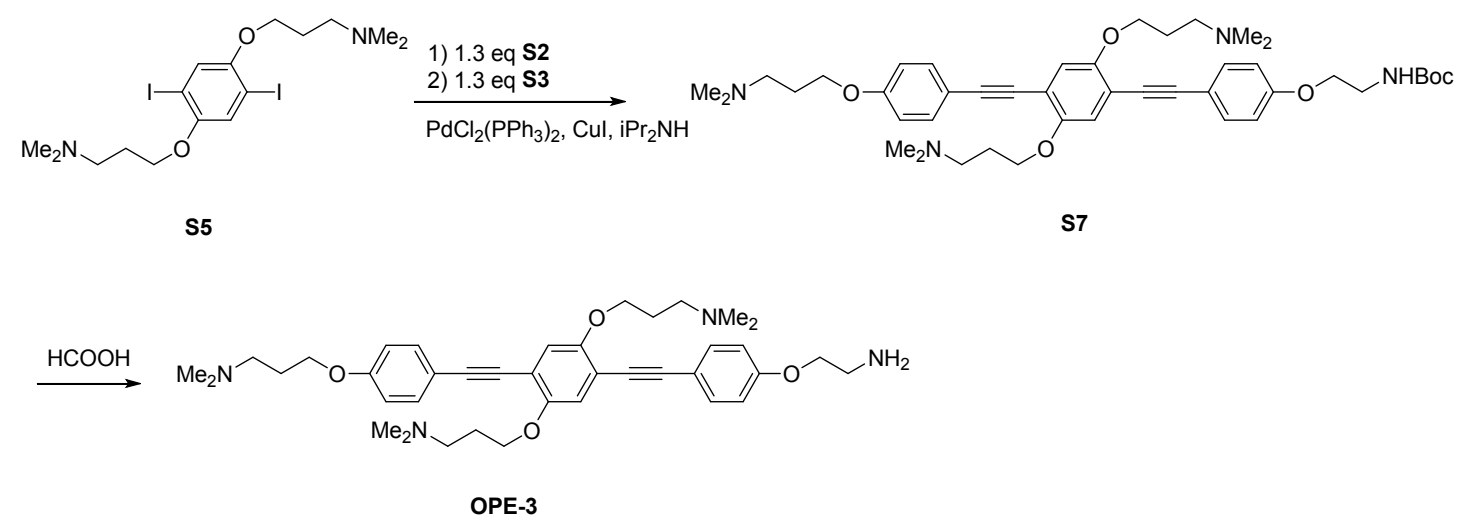

Compound S7. Compound S5 (0.3004 g, $0.56 \mathrm{mmol})$, Compound S2 (0.1908 g, $0.73 \mathrm{mmol}), \mathrm{Pd}\left(\mathrm{PPh}_{3}\right) \mathrm{Cl}_{2}(0.0196 \mathrm{~g}, 0.028 \mathrm{mmol}), \mathrm{CuI}(0.0106$ $\mathrm{g}, \quad 0.056 \mathrm{mmol}$ ) and $6 \mathrm{~mL}$ THF were mixed and degassed by purging with argon gas for 5 minutes, then diisopropylamine $(0.2828 \mathrm{~g}, 2.8$ mmol) was added via a injector. After the mixture was stirred for 12 hours, compound $\mathbf{S 3}(0.1484 \mathrm{~g}, 0.73 \mathrm{mmol})$ was added, then reaction mixture was stirred for another 12 hours. The mixture was concentrated and the residue was purified by flash column chromatography with silica gel which was washed by solution of $\mathrm{MeOH}$ and $\mathrm{CH}_{2} \mathrm{Cl}_{2}$ to afford yellow 
solid S7, (0.1921 g, $0.26 \mathrm{mmol})$, yield 46\%.

Compound OPE-3. Compound S7 (0.1921 g, $0.26 \mathrm{mmol})$ was added to 1 $\mathrm{mL}$ formic acid and stirred at room temperature for 12 hours. The mixture was concentrated and the residue was added $20 \mathrm{~mL} 1 \mathrm{~mol} / \mathrm{L} \mathrm{NaOH}$ solution. Extraction of solution three times using $\mathrm{CH}_{2} \mathrm{Cl}_{2}$ and the $\mathrm{CH}_{2} \mathrm{Cl}_{2}$ solution was washed by $1 \mathrm{~mol} / \mathrm{L} \mathrm{NaOH}$ solution, water, saturated $\mathrm{NaCl}$ solution successively and dried by anhydrous $\mathrm{NaSO}_{4}$ for 4 hours. Removing the $\mathrm{NaSO}_{4}$ through filtration, the organic phase was concentrated to afford yellow solid OPE-3 (0.1199 g, $0.19 \mathrm{mmol})$, yield 73\%. ${ }^{1} \mathrm{H}$ NMR (400 MHz, DMSO) $\delta 7.48-7.40(\mathrm{~m}, 4 \mathrm{H}), 7.11(\mathrm{~s}, 2 \mathrm{H})$, $7.04-6.94(\mathrm{~m}, 4 \mathrm{H}), 4.09-4.00(\mathrm{~m}, 6 \mathrm{H}), 3.97(\mathrm{t}, \mathrm{J}=5.7 \mathrm{~Hz}, 2 \mathrm{H}), 2.90(\mathrm{~s}$, 2H), $2.43(\mathrm{t}, \mathrm{J}=7.1 \mathrm{~Hz}, 4 \mathrm{H}), 2.34(\mathrm{t}, \mathrm{J}=7.1 \mathrm{~Hz}, 2 \mathrm{H}), 2.14(\mathrm{~s}, 6 \mathrm{H}), 2.13$ (s, 12H), $1.91-1.79(\mathrm{~m}, 6 \mathrm{H}) .{ }^{13} \mathrm{C}$ NMR (101 MHz, DMSO) $\delta 158.98$, $152.89,132.71,116.35,114.94,114.88,114.45,114.37,113.22,113.19$, $94.74,84.73,69.98,67.12,65.96,55.68,55.56,45.23,45.19,27.00$, 26.79. HRMS[ESI]: calcd for $\mathrm{C}_{39} \mathrm{H}_{52} \mathrm{~N}_{4} \mathrm{O}_{4}(\mathrm{M}+\mathrm{H})^{+}$, 641.4061; found, 641.4030. 


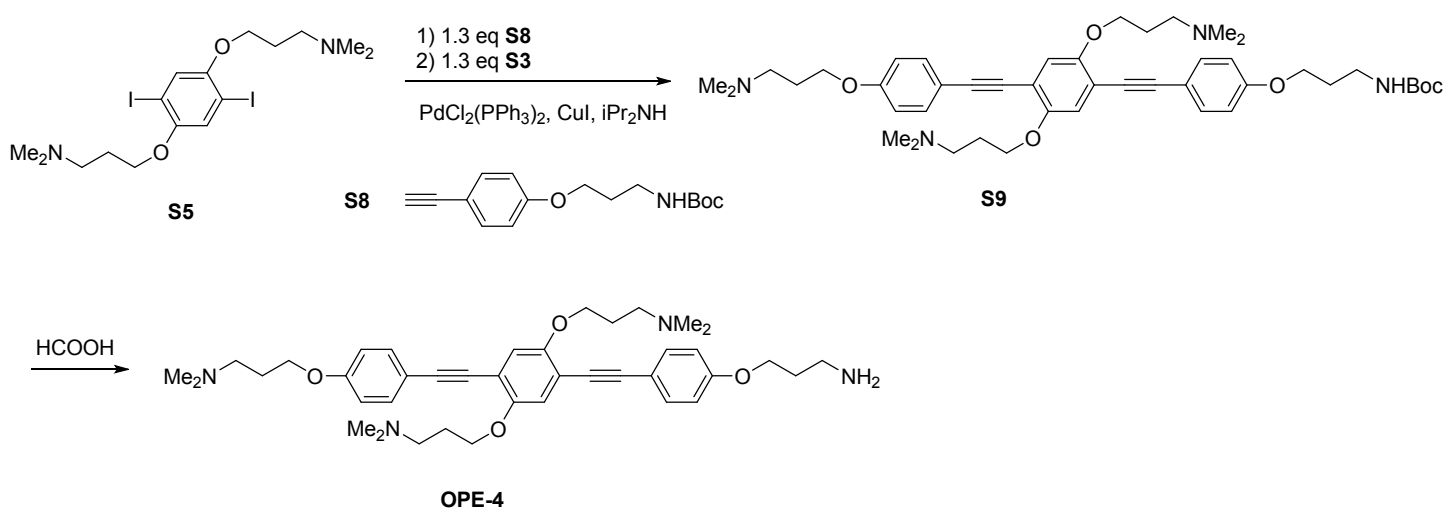

Compound S9. Compound S5 (0.1002 g, 0.19 mmol), Compound S2 (0.0653 g, $0.25 \mathrm{mmol}), \mathrm{Pd}\left(\mathrm{PPh}_{3}\right) \mathrm{Cl}_{2}(0.0133 \mathrm{~g}, 0.019 \mathrm{mmol}), \mathrm{CuI}(0.0072$ $\mathrm{g}, \quad 0.038 \mathrm{mmol}$ ) and $3 \mathrm{~mL}$ THF were mixed and degassed by purging with argon gas for 5 minutes, then diisopropylamine $(0.0960 \mathrm{~g}, 0.95$ mmol) was added via a injector. After the mixture was stirred for 12 hours, compound $\mathbf{S 8}(0.0508 \mathrm{~g}, 0.25 \mathrm{mmol})$ was added, then reaction mixture was stirred for another 12 hours. The mixture was concentrated and the residue was purified by flash column chromatography with silica gel which was washed by solution of $\mathrm{MeOH}$ and $\mathrm{CH}_{2} \mathrm{Cl}_{2}$ to afford yellow solid S9, (0.0339 g, $0.045 \mathrm{mmol})$, yield 21\%.

Compound OPE-4. Compound S9 (0.0339 g, 0.045 mmol) was added to $1 \mathrm{~mL}$ formic acid and stirred at room temperature for 12 hours. The mixture was concentrated and the residue was added $20 \mathrm{~mL} 1 \mathrm{~mol} / \mathrm{L}$ $\mathrm{NaOH}$ solution. Extraction of solution three times using $\mathrm{CH}_{2} \mathrm{Cl}_{2}$ and the $\mathrm{CH}_{2} \mathrm{Cl}_{2}$ solution was washed by $1 \mathrm{~mol} / \mathrm{L} \mathrm{NaOH}$ solution, water, saturated $\mathrm{NaCl}$ solution successively and dried by anhydrous $\mathrm{NaSO}_{4}$ for 4 hours. Removing the $\mathrm{NaSO}_{4}$ through filtration, the organic phase was 
concentrated to afford yellow solid OPE-4 (0.0270 g, $0.041 \mathrm{mmol})$, yield 91\%. ${ }^{1} \mathrm{H}$ NMR (400 MHz, DMSO) $\delta 7.44(\mathrm{dd}, \mathrm{J}=8.8,2.1 \mathrm{~Hz}, 4 \mathrm{H}), 7.10$ (s, 2H), $7.03-6.90(\mathrm{~m}, 4 \mathrm{H}), 4.15-3.97(\mathrm{~m}, 8 \mathrm{H}), 2.73(\mathrm{~s}, 2 \mathrm{H}), 2.43(\mathrm{t}, \mathrm{J}$ $=7.1 \mathrm{~Hz}, 3 \mathrm{H}), 2.34(\mathrm{t}, \mathrm{J}=7.1 \mathrm{~Hz}, 3 \mathrm{H}), 2.14(\mathrm{~s}, 6 \mathrm{H}), 2.13(\mathrm{~s}, 12 \mathrm{H}), 2.05-$ $1.91(\mathrm{~m}, 2 \mathrm{H}), 1.91-1.79(\mathrm{~m}, 8 \mathrm{H}) \cdot{ }^{13} \mathrm{C}$ NMR (101 MHz, DMSO) $\delta$ $158.97,152.89,132.71,114.88,84.73,67.12,65.95,65.58,55.68,55.56$, 45.22, 27.00, 26.79. HRMS[ESI]: calcd for $\mathrm{C}_{40} \mathrm{H}_{54} \mathrm{~N}_{4} \mathrm{O}_{4}(\mathrm{M}+\mathrm{H})^{+}$, 655.4218; found, 655.4159 .

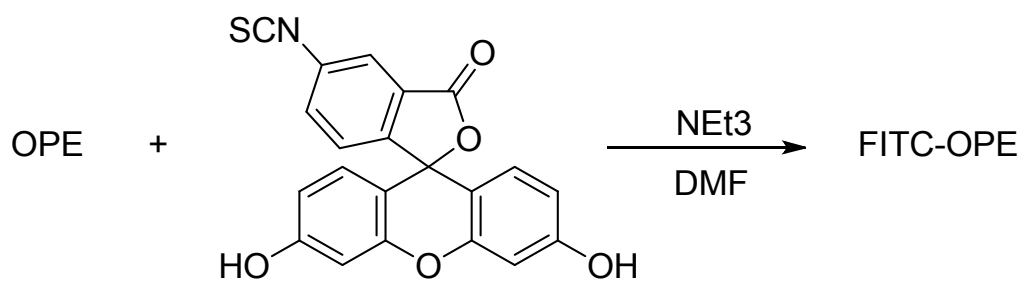

General procedure: $0.01 \mathrm{mmol}$ OPE, $0.01 \mathrm{mmol}$ FITC-NCS and $1 \mu \mathrm{L}$ $\mathrm{NEt}_{3}$ were dissolved in $200 \mu \mathrm{L}$ DMF and stirred overnight at room temperature. Until the reaction completed, the mixture was separated using HPLC (acetonitrile and water), products were confirmed by LC-MS.

All four FITC-NCS were synthesized following above procedure. 


\subsection{NMR Spectra}

OPE-1
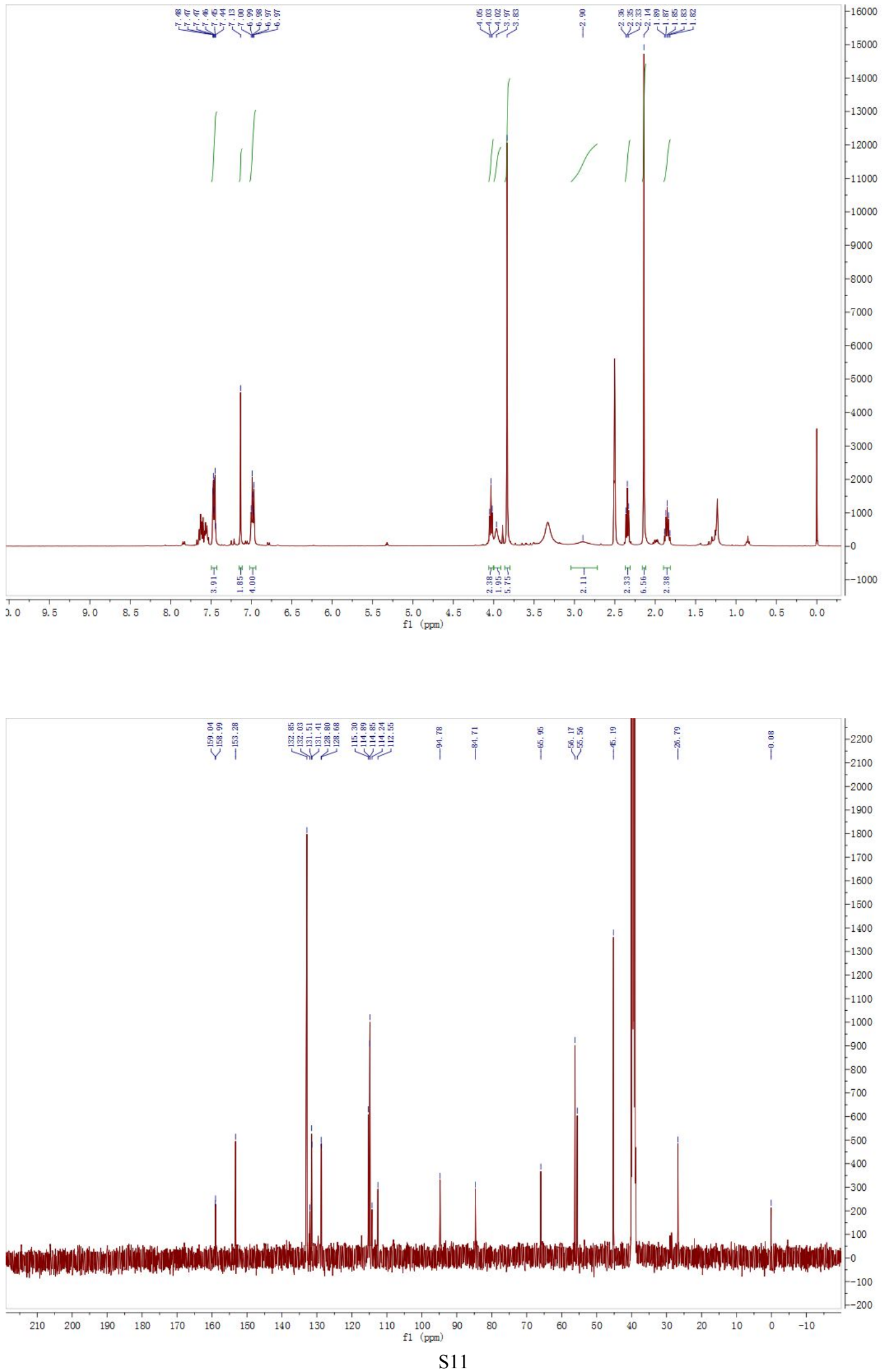


\section{OPE-2}

OPE-3
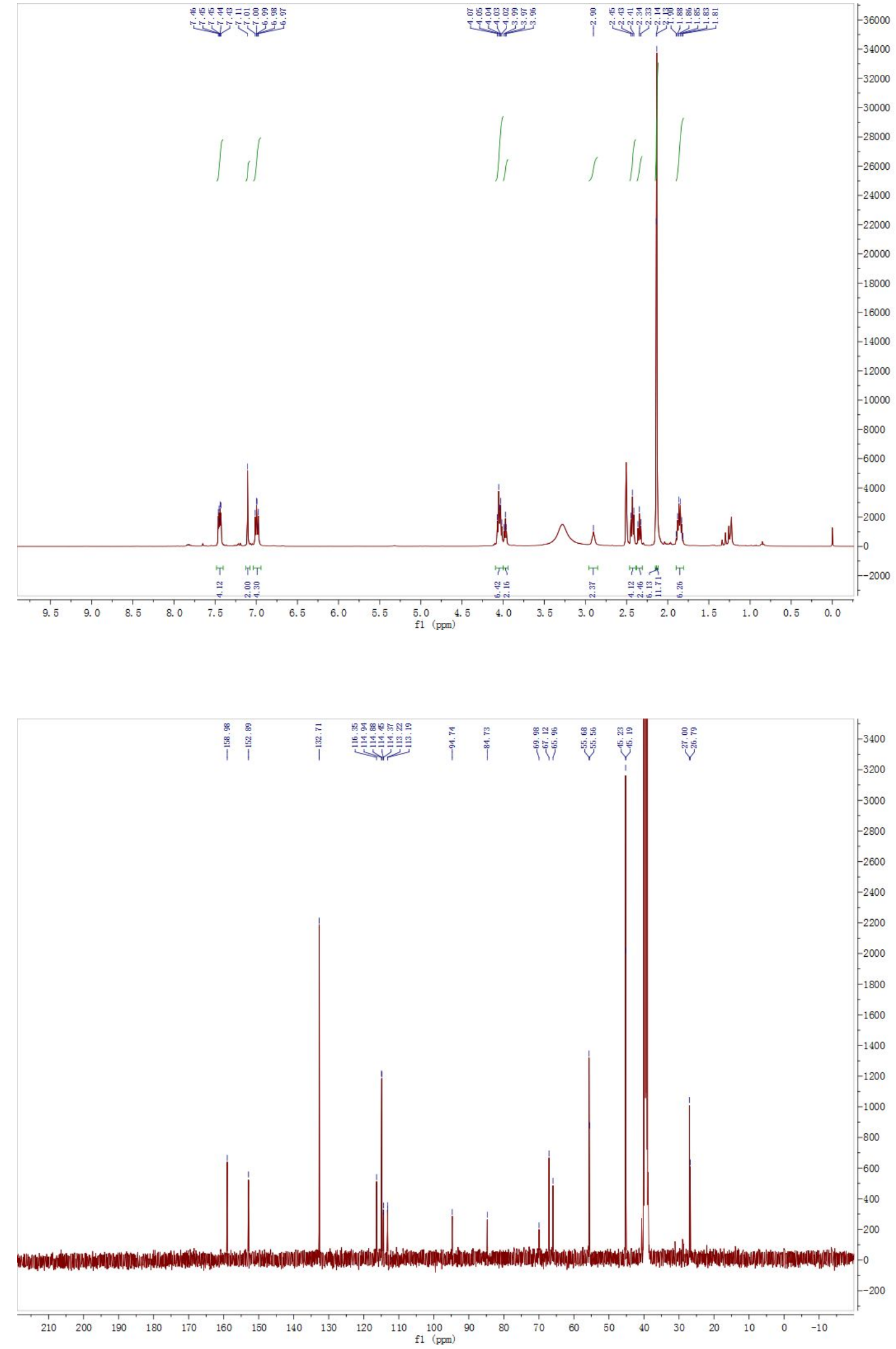


\section{OPE-4}
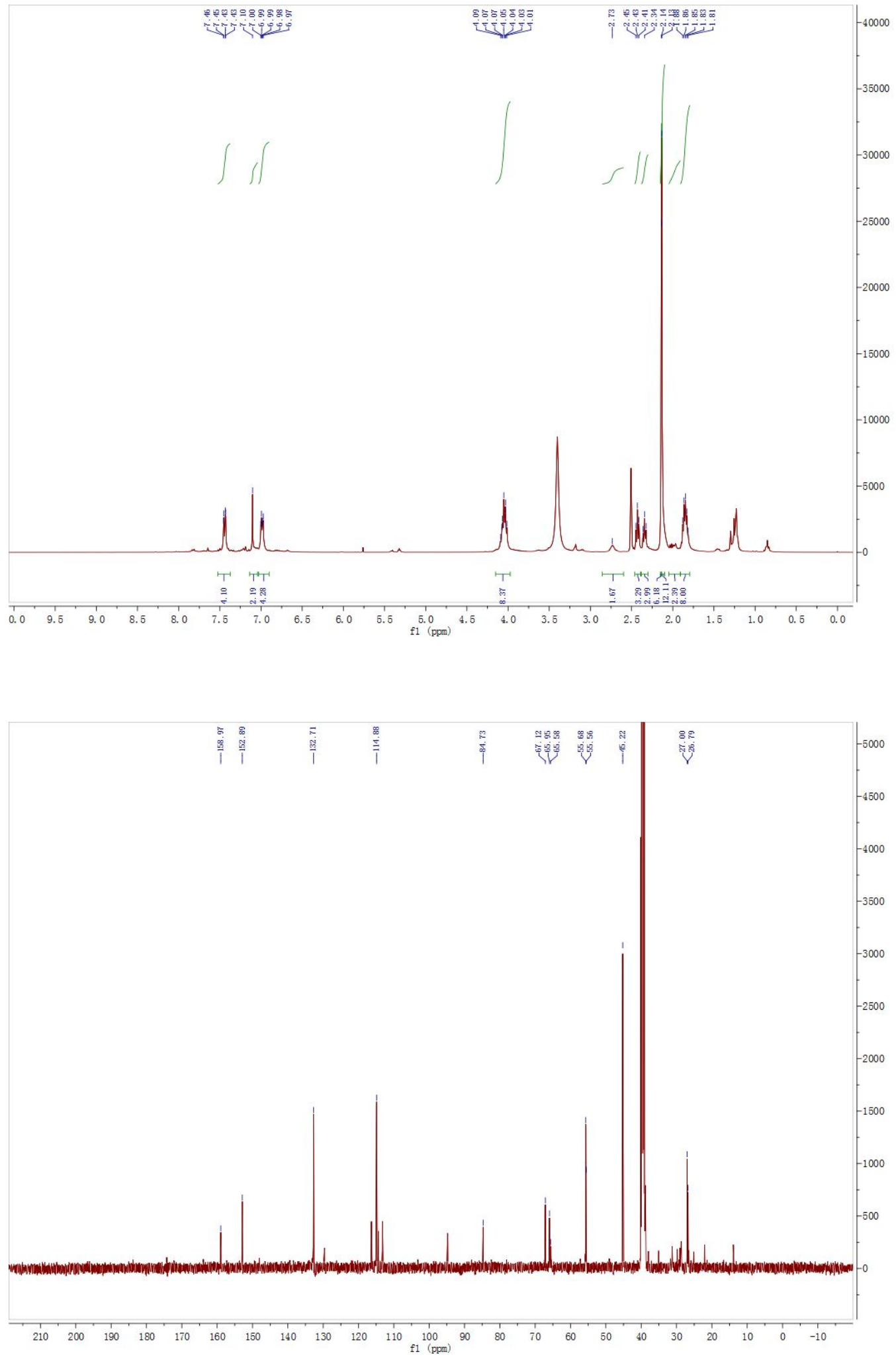


\subsection{Bacterial Growth Conditions}

Gram-positive bacterium S. aureus and Gram-negative bacterium E. coli were chosen for this study. Bacterial samples were transferred from the frozen the states to the agar slants (1.5\% agar and standard Luria broth) for both S. aureus and E. coli and incubated at $37{ }^{\circ} \mathrm{C}$ for $18 \mathrm{~h}$ and then held at $4{ }^{\circ} \mathrm{C}$ for up to 2 weeks. A single colony from the slants was incubated in $25 \mathrm{~mL} \mathrm{LB}$ and grown at $30{ }^{\circ} \mathrm{C}$ for $18 \mathrm{~h}$ with shaking. After growth, the bacterial culture was centrifuged at $4000 \mathrm{rpm}$ for 5 minutes. The pellet was resuspended in $25 \mathrm{~mL} 0.9 \% \mathrm{NaCl}$ solution after removing the LB and centrifuged. The washing procedure was repeated twice. The cell pellet was resuspended in $0.9 \% \mathrm{NaCl}$ solution and $\mathrm{OD}_{600}$ was adjusted to 1.0. The cell suspension was diluted 100 times by $0.9 \% \mathrm{NaCl}$ and final concentration of bacteria was about $10^{7}$ cell $/ \mathrm{mL}$.

\subsection{Bacterial Killing Experiments}

To test the antibacterial activities of OPE-1, OPE-2, OPE-3 and OPE-4, Gram-negative bacteria $E$. coli and Gram-positive $S$. aureus were incubated with different concentration of OPEs $(1.0,3.0,9.0 \mu \mathrm{g} / \mathrm{mL}$ for Gram-negative bacteria $E$. coli and $0.1,0.3$ and $0.9 \mu \mathrm{g} / \mathrm{mL}$ for Gram-positive $S$. aureus $)$ in the dark or light $\left(90 \mathrm{mw} / \mathrm{cm}^{2}\right)$ for 30 or 60 minutes. After the bacteria was incubated with the OPEs, the suspension 
was added a 1:1 ratios of dyes and kept in the dark for 15 minutes. The stains for Gram-negative bacteria E. coli are SYTO 9(green fluorescence) and propidium iodide (PI, red fluorescence). The stains for Gram-positive S. aureus are SYTO 24 (green fluorescence) and propidium iodide (PI, red fluorescence). The final concentration of SYTO 9, SYTO 24 and PI were $1.25 \mu \mathrm{mol} / \mathrm{L}, 0.25 \mu \mathrm{mol} / \mathrm{L}$ and $7.5 \mu \mathrm{mol} / \mathrm{L}$, respectively. Finally, the stained bacteria were examined using flow cytometry and fluorescence microscope.

\subsection{Preparation of Fluorescein-Loaded Vesicles and Vesicle Leakage Assays}

Fluorescence-loaded liposomes were prepared by extrusion. $\mathrm{A} \mathrm{CHCl}_{3}$ solution of phospholipid was dried by rotary evaporator for 3 hours at $55{ }^{\circ} \mathrm{C}$. The dried lipid film was hydrated using $1 \mathrm{~mL} 100 \mathrm{mmol} / \mathrm{L}$ fluorescence solution of PBS buffer (adjusted to $\mathrm{pH} 7.4$ with $\mathrm{NaOH}$ ) with strong shaking for $10 \mathrm{~min}$ at temperature above the phase-transition temperature of the lipid. Then the liposomes were formed by extruding the lipid solution 23 times through a 200-nm-pore-size polycarbonate membrane using a mini-extruder (Avanti Polar Lipids). Free fluorescence was removed from the dye-loaded liposome by column filtration (Sephadex G-25 superfine) washing with PBS buffer. The hydrodynamic diameter and net surface charge of the liposomes were tested by dynamic 
light scattering (DLS, Nano Series, Malvern Corporation).

The liposome was diluted to proper concentration to use. The maximum fluorescence intensity of the liposome is achieved by addition of $10 \%$ Triton X100 to the sample.

The interaction of liposome membrane and the OPEs was evaluated by a dye leakage assay. OPE was added to the dye-loaded liposome with a final OPE concentration of $1.0 \mu \mathrm{g} / \mathrm{mL}$ and $2.5 \mu \mathrm{g} / \mathrm{mL}$ for $E$. coli total lipid extract and DOPG, respectively. The OPE perturbed the membrane and the dye is released. The released dye was detected by the microplate reader (Synergy H1 microplate reader, BioTek Instruments. InC., excitation at $485 \mathrm{~nm}$, recorded at $525 \mathrm{~nm}$ ) every five minutes. All experiments were carried out under dark condition.

Fluorescein leakage was calculated using the following equation:

$$
\text { fluorescein leakage percentage }=\frac{F-F_{0}}{F_{\max }-F_{0}}
$$

where $F$ is the fluorescence of the samples after the addition of OPE, $F_{0}$ is the fluorescence intensity upon the addition of OPE, $F_{\max }$ is the maximum fluorescence intensity of the sample, achieved by the addition of $2 \mu \mathrm{L} 10 \%$ Triton X100 solution to $200 \mu \mathrm{L}$ liposome, which caused the complete releases of the dye.

\subsection{Reactive oxygen species(ROS) measurements}

$1.0 \mathrm{~mL} 40 \mu \mathrm{M}$ activated DCFH solution was added OPEs with a final 
concentration $1.0 \mu \mathrm{M}$. The solution was irradiated for 5 min under white light $\left(5 \mathrm{~mW} / \mathrm{cm}^{2}\right)$. The fluorescence spectra were measured with the excitation wavelength of $488 \mathrm{~nm}$ and recorded wavelength $500-700 \mathrm{~nm}$.

\subsection{Observation of Cell Morphology}

Cell pellets exposed to OPEs or the negative control (without OPE) were examined by SEM (Supra55, Karl Zeiss). For SEM imaging, the samples were resuspended in $2.5 \%$ glutaraldehyde and incubated at room temperature overnight to preserve the interface between the cells and antimicrobial agents, followed by washing with PBS buffer. Fixed cells were dehydrated by sequential treatment with increasing concentrations of ethanol for 30 minutes. The dehydrated samples were dried at room temperature and sputter coated with $\sim 10 \mathrm{~nm}$ of gold and palladium under vacuum and subsequently analyzed by SEM.

\subsection{Confocal laser scanning microscopy (CLSM)}

\section{characterization}

E. coli cells was suspended in $0.9 \%$ normal saline with a concentration of $\mathrm{OD}_{600}=1$. The E. coli were cultured at $37^{\circ} \mathrm{C}$ for $1 \mathrm{~h}$ with $10 \mu \mathrm{M}$ FITC-OPE, and the control did not add FITC-OPE. After centrifugation, the bacteria was suspended in $0.9 \%$ normal saline with 3.6 $\mu \mathrm{M}$ DAPI, and then stained for $15 \mathrm{~min}$ at room temperature. Then the bacteria was washed with $0.9 \%$ normal saline twice and suspended in paraformaldehyde solution for $15 \mathrm{~min}$. After centrifugation, the bacteria was washed with $0.9 \%$ normal saline twice. Finally, the washed bacteria 
was suspended with $0.9 \%$ normal saline prepared on glass for confocal imaging.

\subsection{Cytotoxicity}

The cytotoxicity of OPEs against HL-7702 cells was evaluated by MTS assay. HL-7702 cells were seeded into a 96-well plate at a density of 3.0 $\times 10^{4}$ cells per well in $100 \mu \mathrm{L}$ of 1640 nutrient solution for $24 \mathrm{~h}$ at $37^{\circ} \mathrm{C}$ in $5 \% \mathrm{CO}_{2}$. The OPEs was diluted with 1640 and added to the well (100 $\mu \mathrm{L})$ and the cells were incubated for $24 \mathrm{~h}$ in the dark. Then, the cells were washed by PBS, and after removing the PBS, $100 \mu \mathrm{L} 1640$ with MTS was added into each well. The cells were incubated for a further $2 \mathrm{~h}$ and the optical density was read on a microplate reader at $490 \mathrm{~nm}$.

\section{Antibacterial Data}

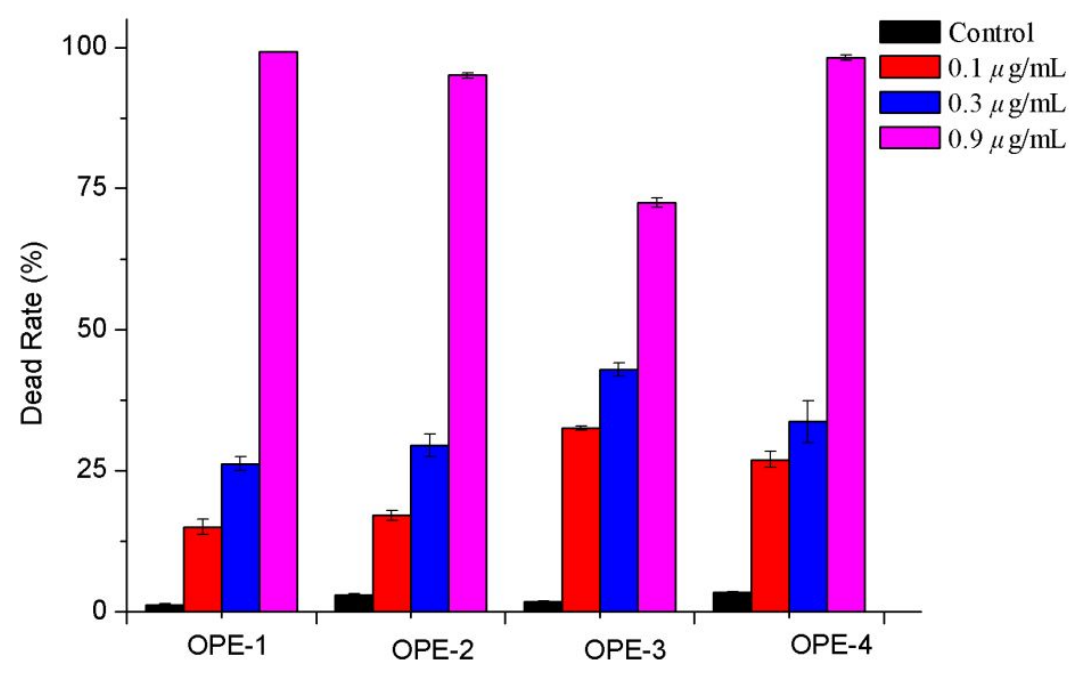

Figure S1. S. aureus against OPEs upon exposed to fiber light at various concentrations for $30 \mathrm{~min}$. The error bars represent the standard deviations of three parallel measurements. 


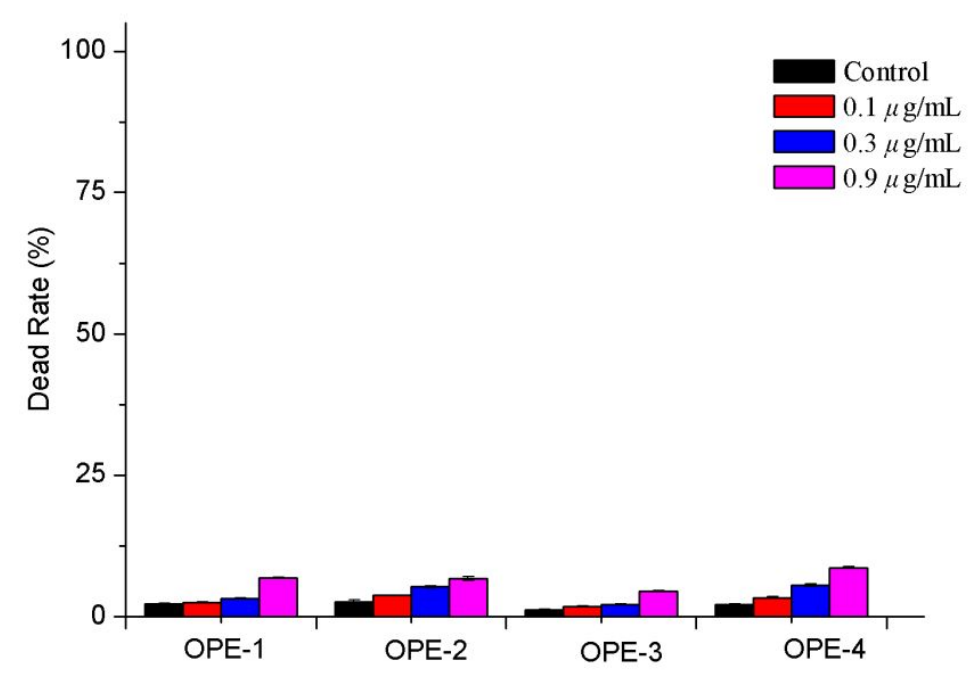

Figure S2. S. aureus against OPEs in the dark at various concentrations for $30 \mathrm{~min}$. The error bars represent the standard deviations of three parallel measurements.

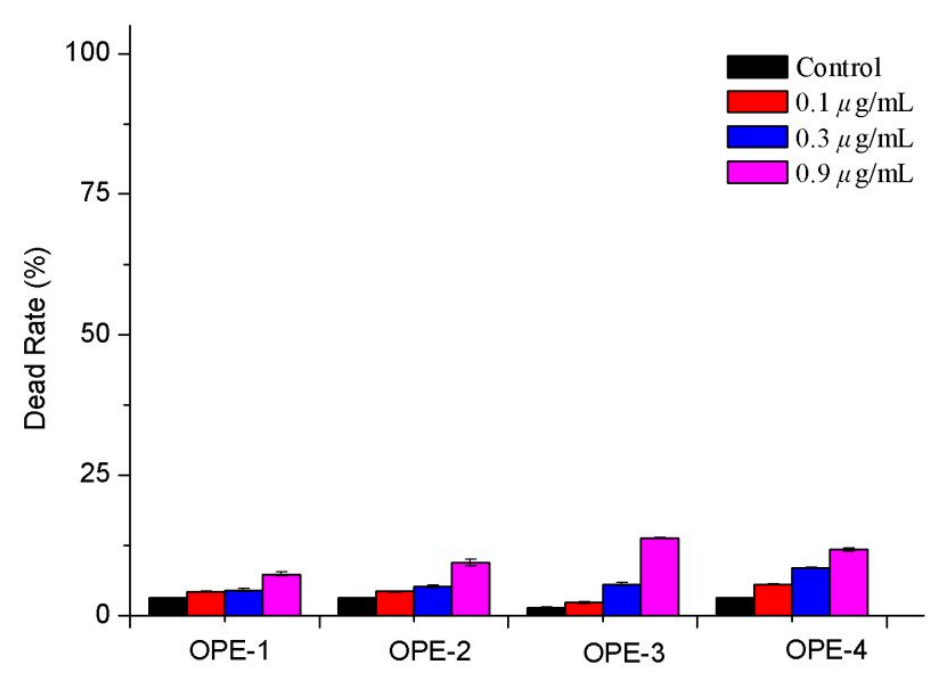

Figure S3. S. aureus against OPEs in the dark at various concentrations for $60 \mathrm{~min}$. The error bars represent the standard deviations of three parallel measurements. 


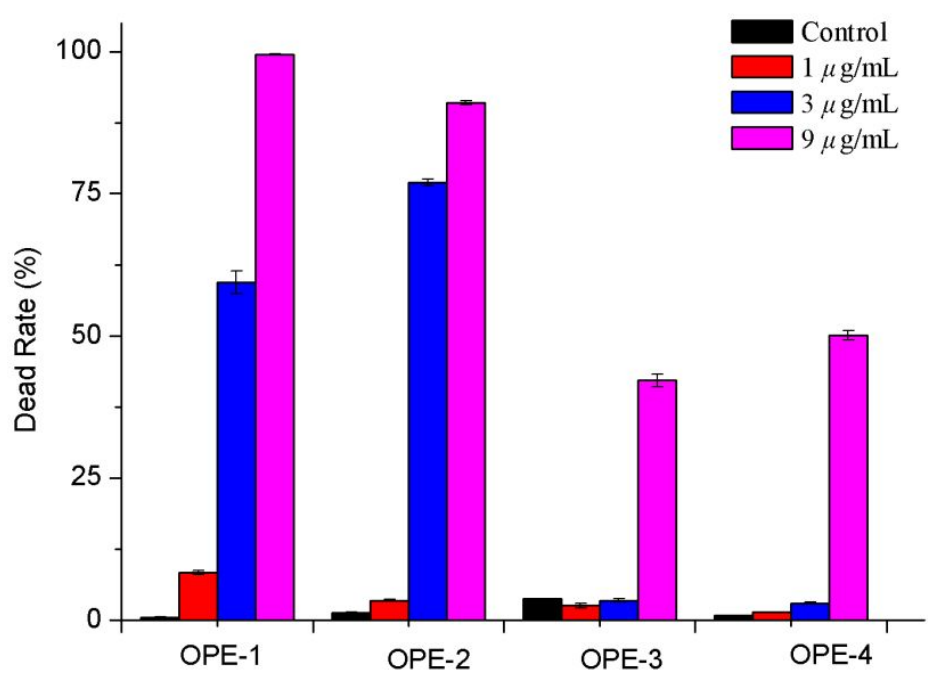

Figure S4. E. coli against OPEs upon exposed to fiber light at various concentrations for $30 \mathrm{~min}$. The error bars represent the standard deviations of three parallel measurements.

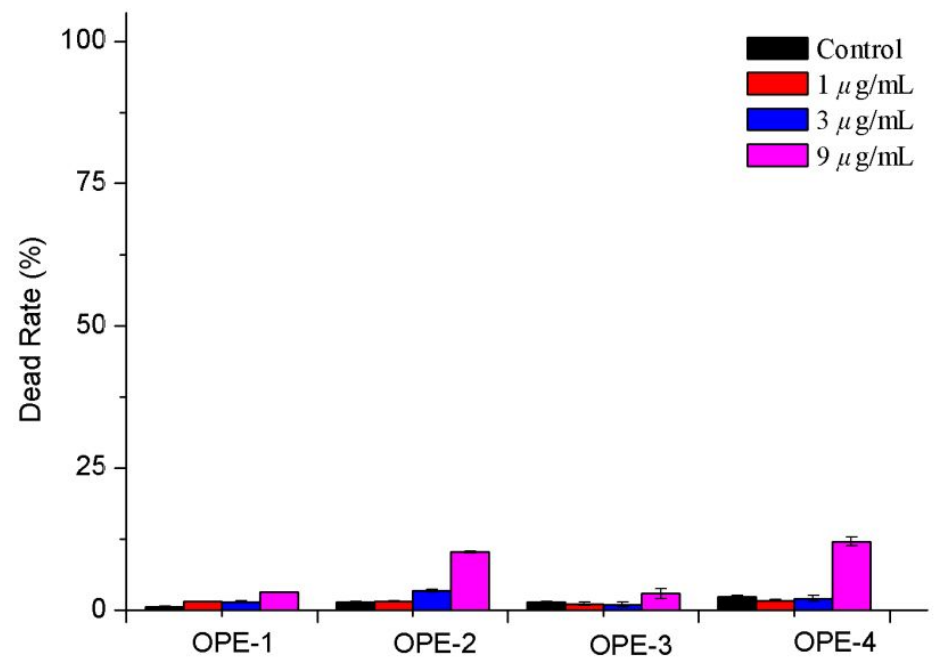

Figure S5. E. coli against OPEs upon in the dark at various concentrations for $30 \mathrm{~min}$. The error bars represent the standard deviations of three parallel measurements. 


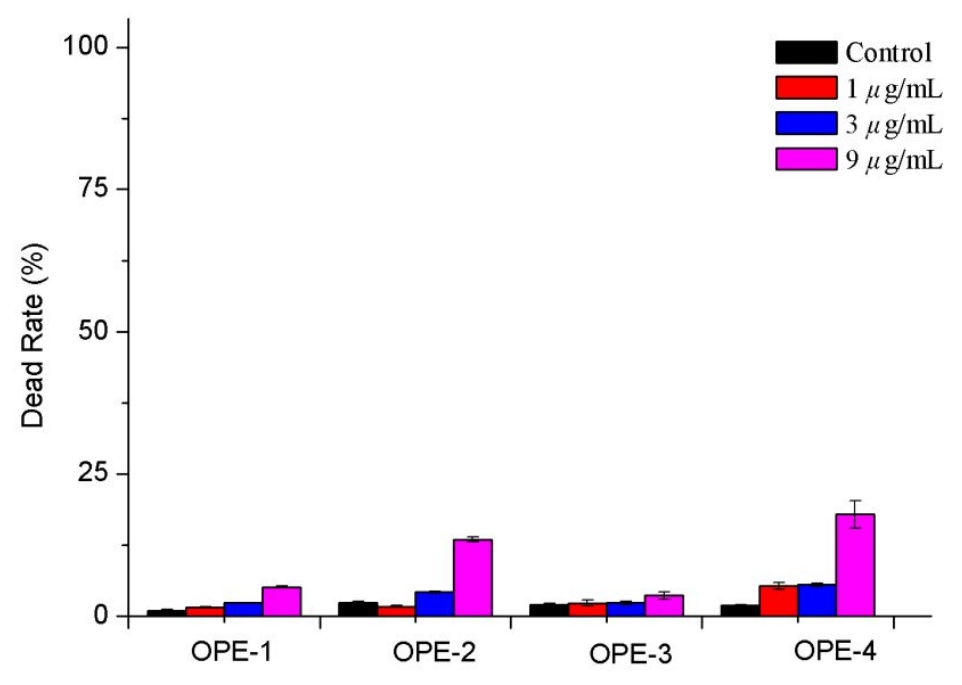

Figure S6. E. coli against OPEs upon in the dark at various concentrations for $60 \mathrm{~min}$. The error bars represent the standard deviations of three parallel measurements.

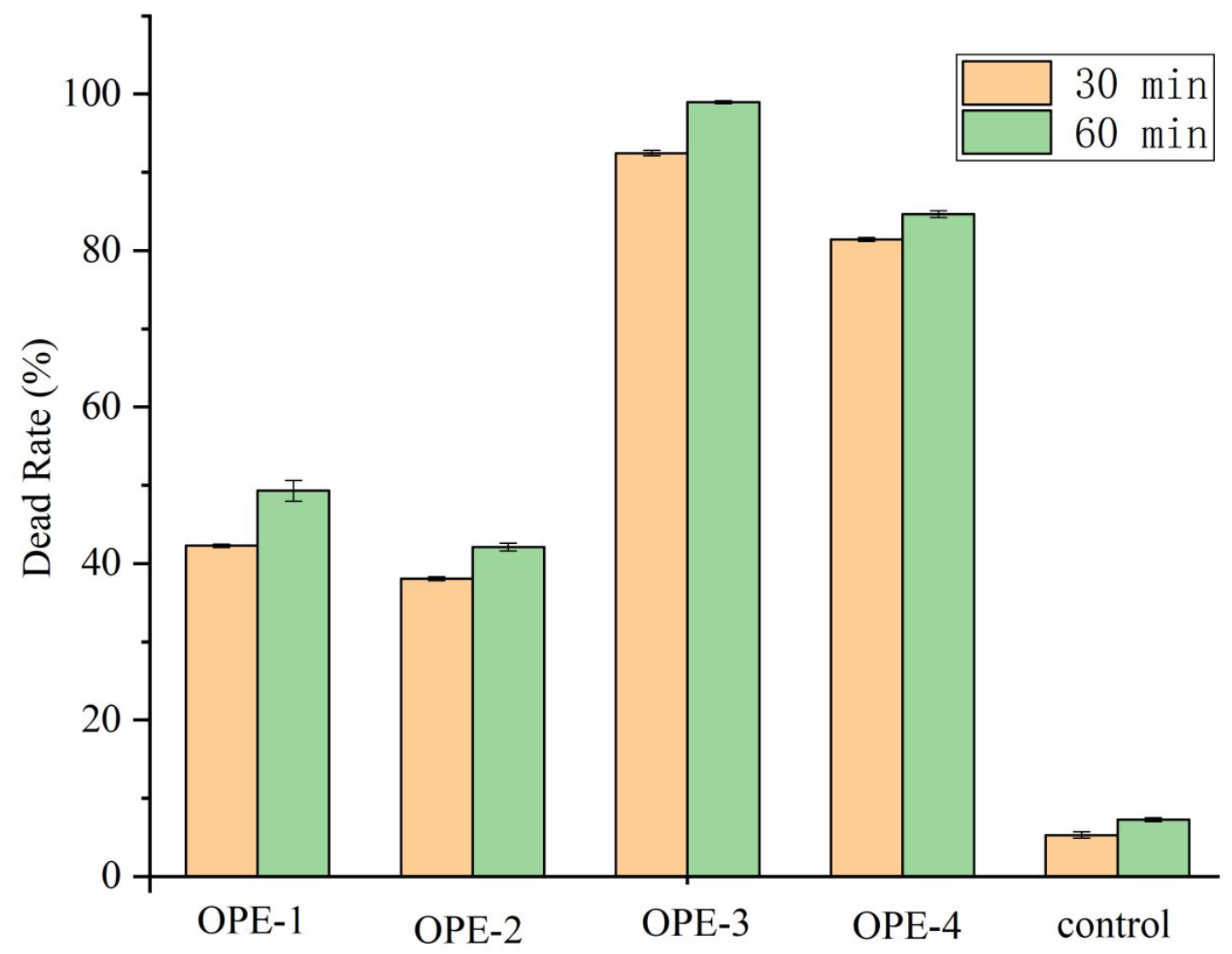

Figure S7. S. aureus against OPEs in the dark at $9 \mu \mathrm{g} / \mathrm{mL}$. The error bars represent the standard deviations of three parallel measurements. 


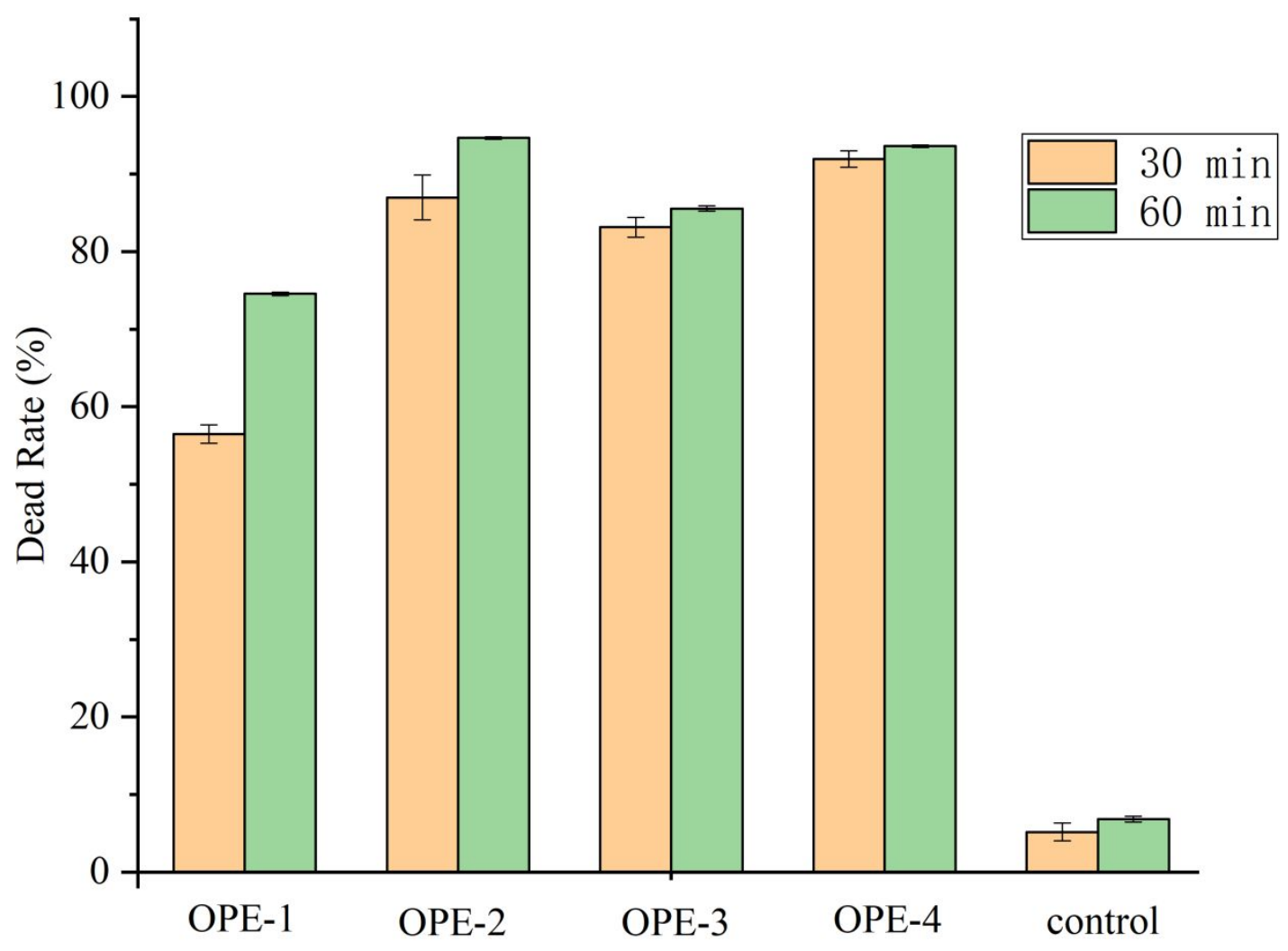

Figure S8. E. coli against OPEs upon in the dark at $90 \mu \mathrm{g} / \mathrm{mL}$. The error bars represent the standard deviations of three parallel measurements. 


\section{Emission spectra of light source}

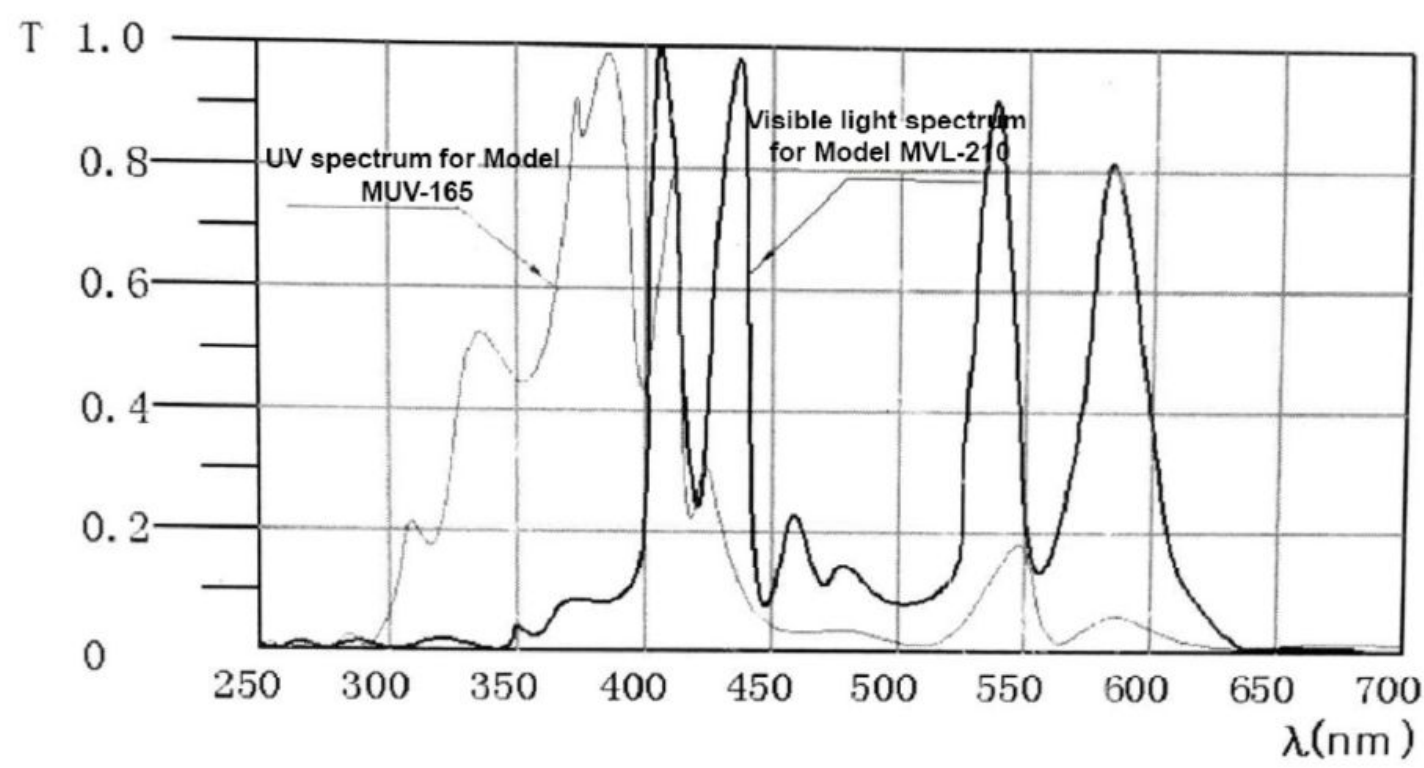

Figure S9. Emission spectra of light source (black solid line). Gray line: UV spectrum for Model MUV-165; black solid line for Model MVL-210, which is the light source used in this study. Spectra are from the light source manual of Mejiro Genossen Inc. Japan.

\section{Absorption and Fluorescence Spectra of OPEs}




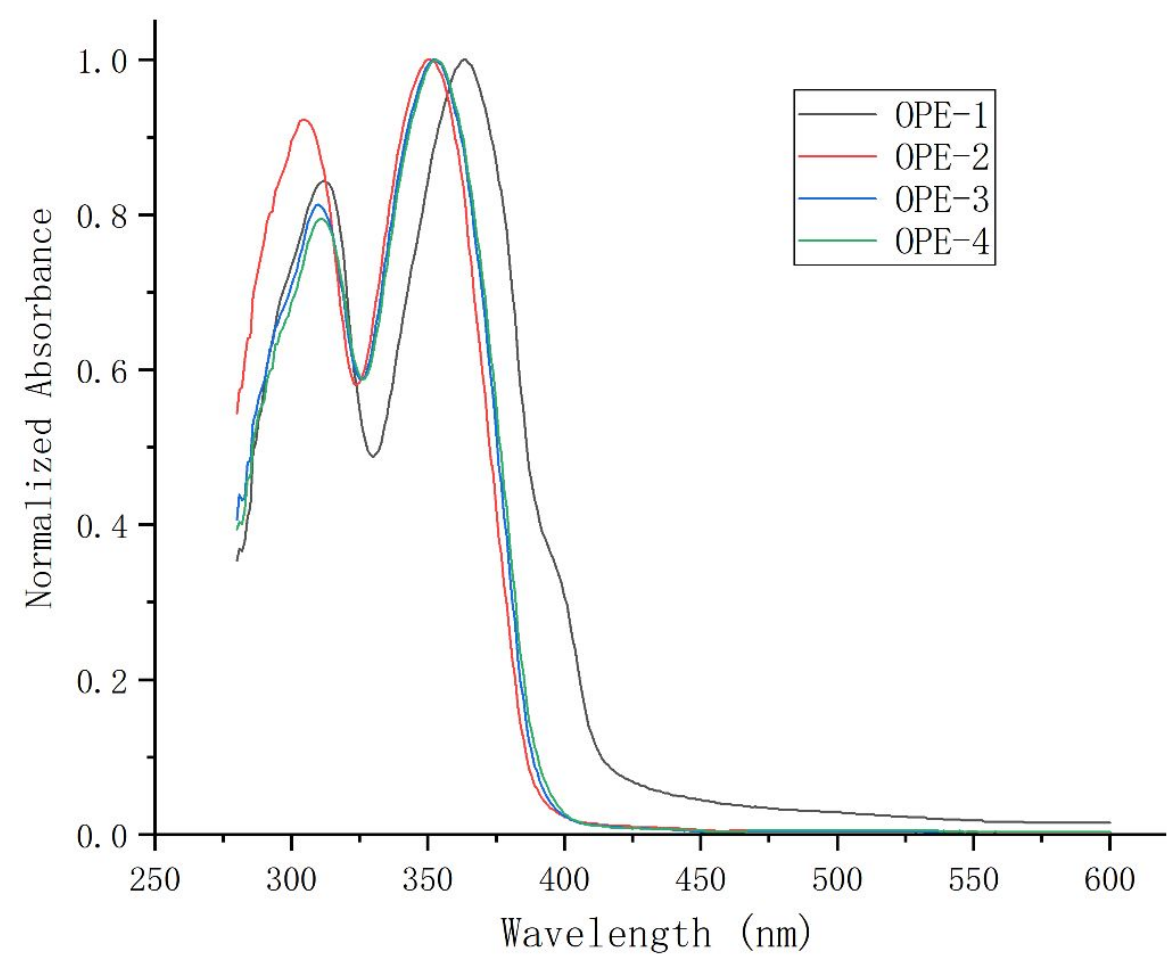

Figure S10. Absorption spectra of OPEs in water.

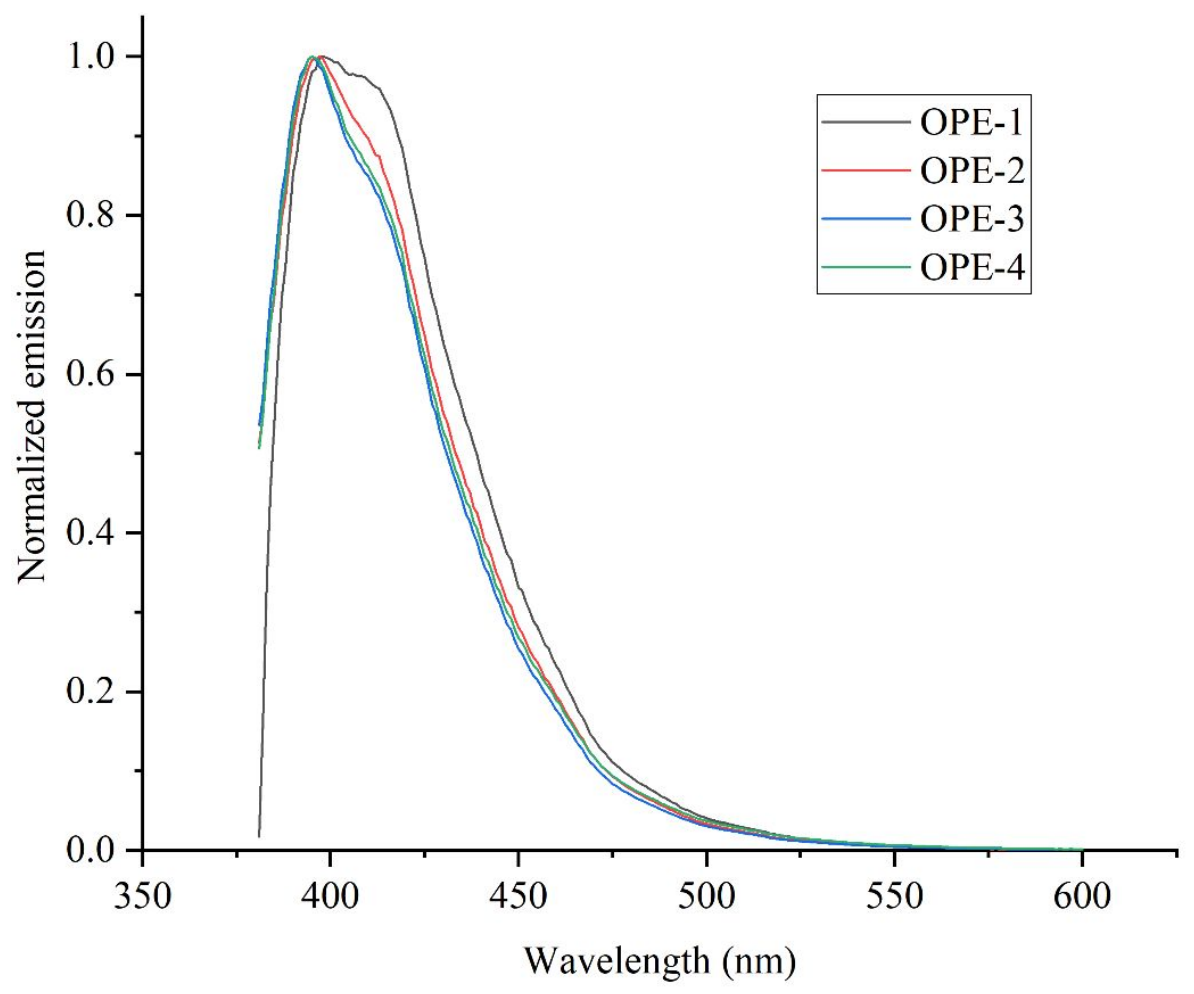

Figure S11 Fluorescence spectra of OPEs in water. 


\section{Image of $E$. coli stained by DAPI and FITC}

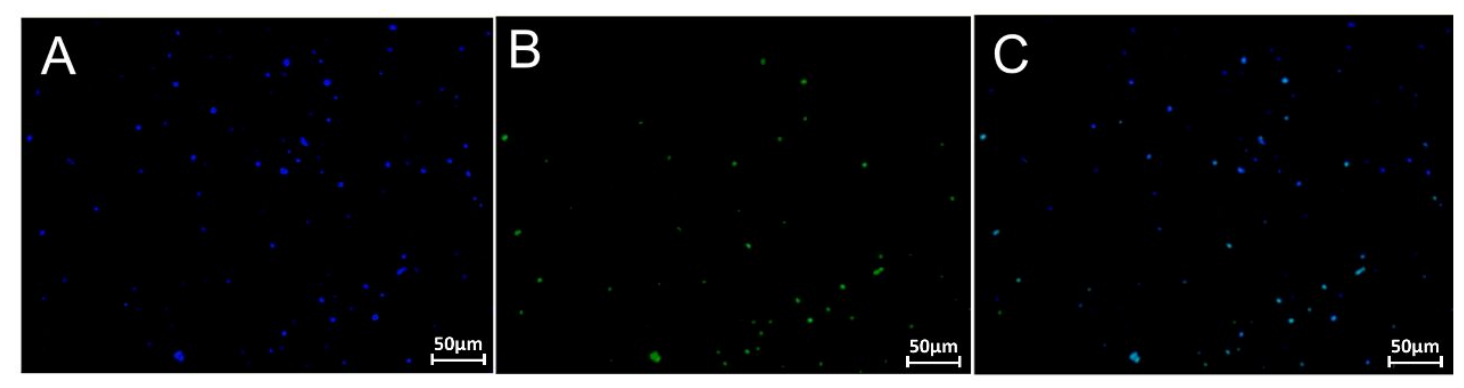

Figure S12. Fluorescence microscope images of E. coli stained by FITC-OPE-1 and DAPI. The images of E. coli stained by DAPI and FITC, and the merged images are named by a, b and c, respectively. Scale bars are $50 \mu \mathrm{m}$.

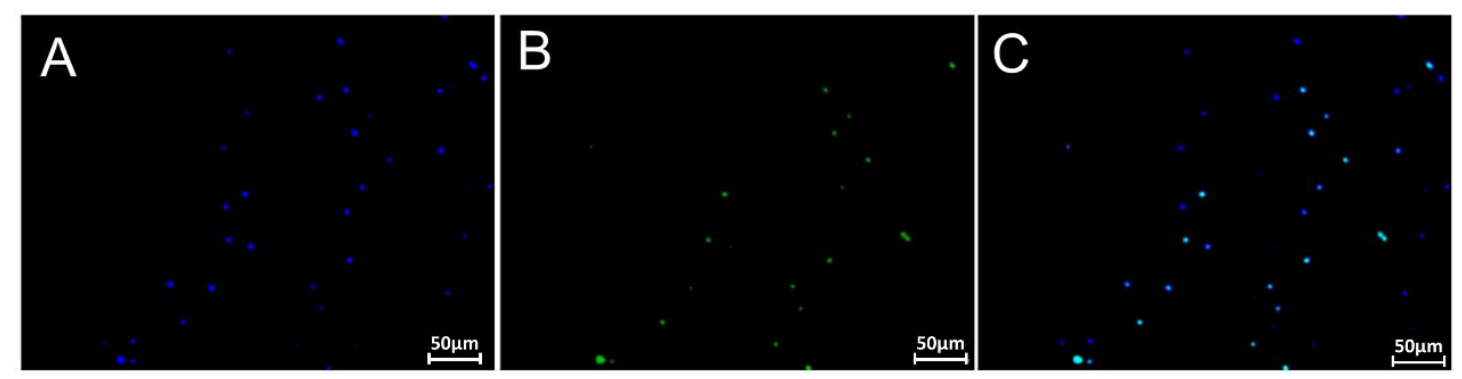

Figure S13. Fluorescence microscope images of E. coli stained by FITC-OPE-2 and DAPI. The images of E. coli stained by DAPI and FITC, and the merged images are named by $a, b$ and c, respectively. Scale bars are $50 \mu \mathrm{m}$.

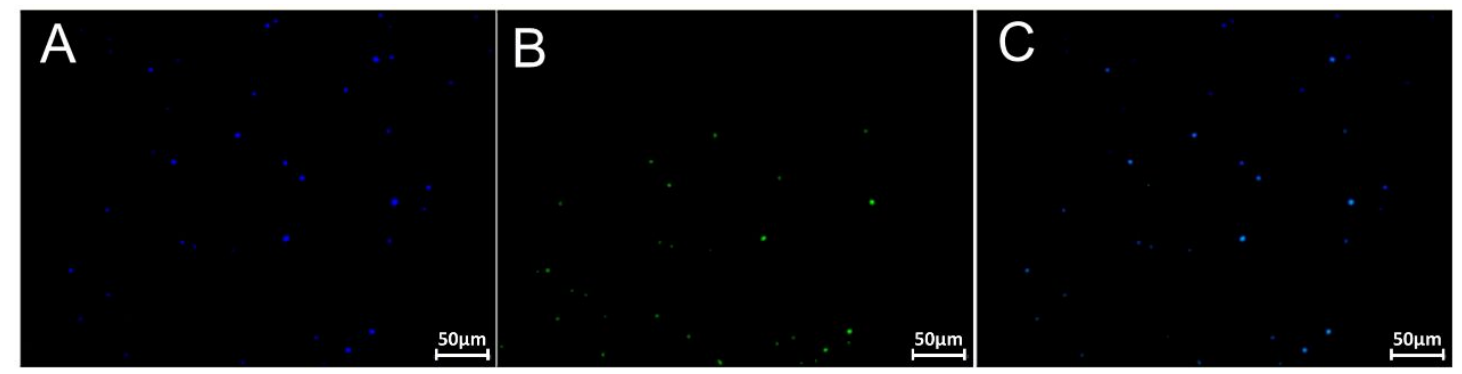


Figure S14. Fluorescence microscope images of $E$. coli stained by FITC-OPE-3 and DAPI. The images of E. coli stained by DAPI and FITC, and the merged images are named by a, b and c, respectively. Scale bars are $50 \mu \mathrm{m}$.

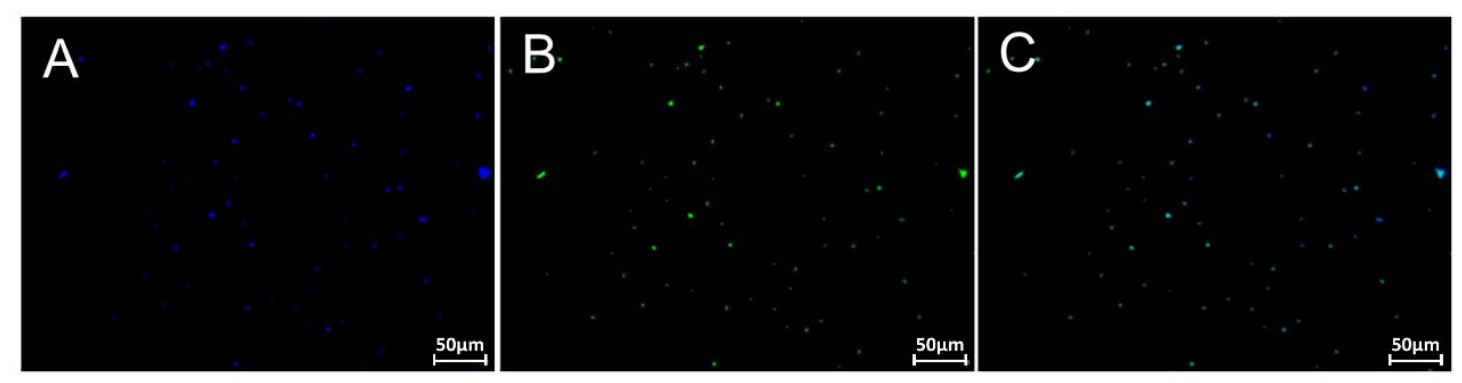

Figure S15. Fluorescence microscope images of $E$. coli stained by FITC-OPE-4 and DAPI. The images of E. coli stained by DAPI and FITC, and the merged images are named by $a, b$ and c, respectively. Scale bars are $50 \mu \mathrm{m}$.

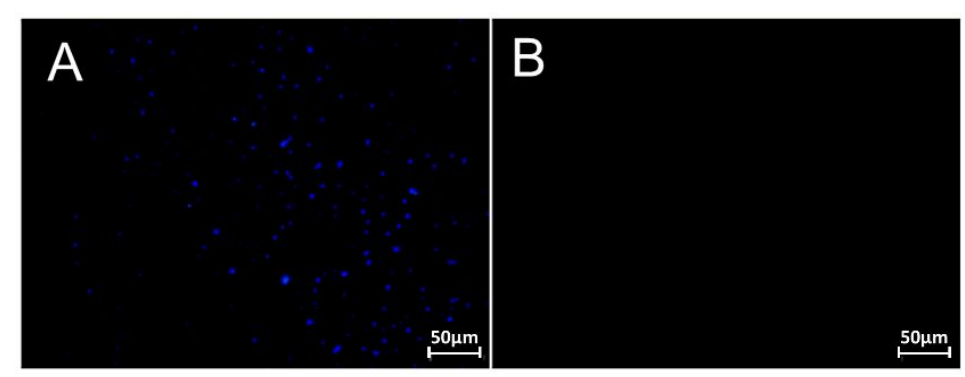

Figure S16. Fluorescence microscope images of E. coli stained by DAPI. The images of $E$. coli stained by DAPI and FITC are named by a and b, respectively. Scale bars are $50 \mu \mathrm{m}$.

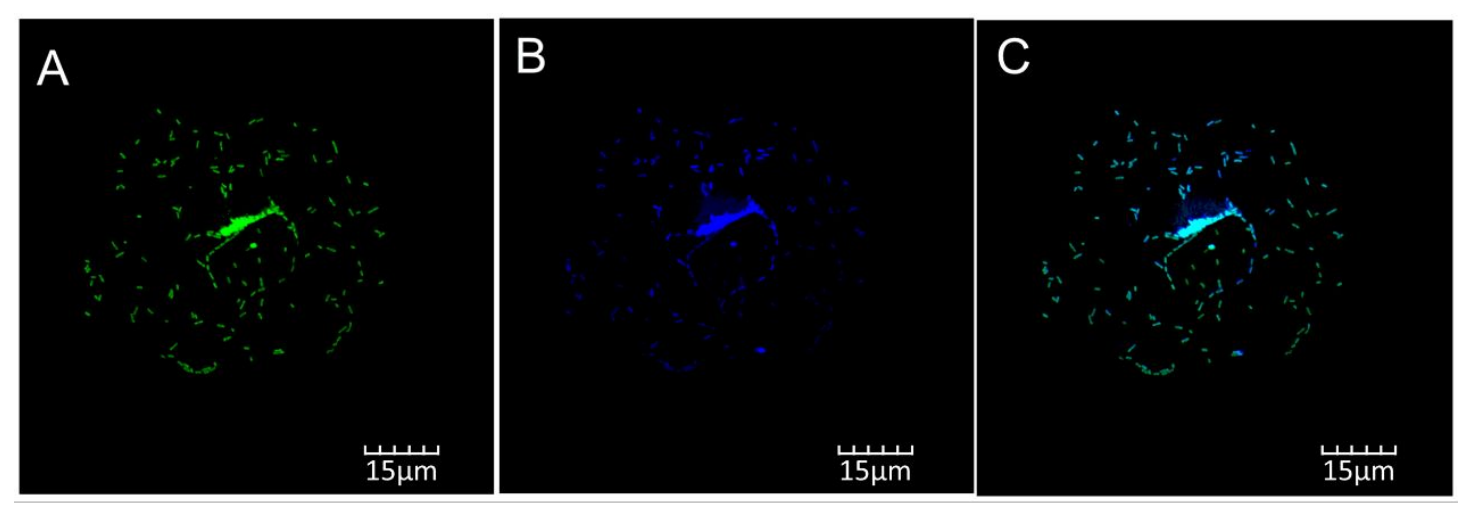

Figure S17. CLSM images of E. coli stained by FITC-OPE-2 and DAPI. 
The images of $E$. coli stained by DAPI and FITC, and the merged images are named by $a, b$ and $c$, respectively. Scale bars are $15 \mu \mathrm{m}$.

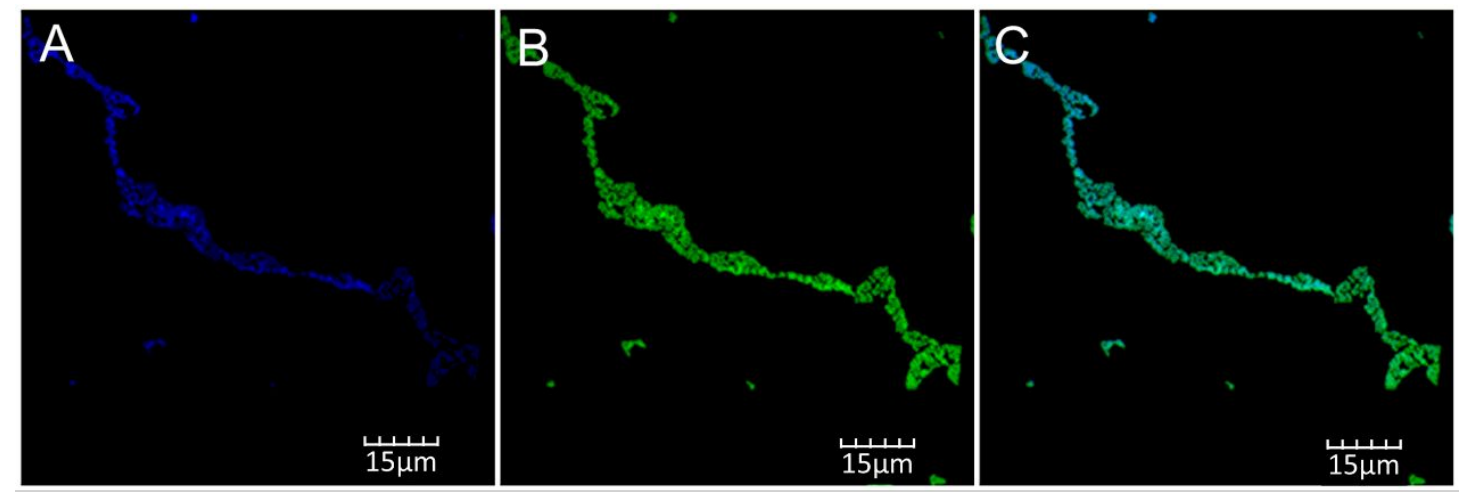

Figure S18. CLSM images of E. coli stained by FITC-OPE-3 and DAPI. The images of $E$. coli stained by DAPI and FITC, and the merged images are named by $\mathrm{a}, \mathrm{b}$ and $\mathrm{c}$, respectively. Scale bars are $15 \mu \mathrm{m}$.

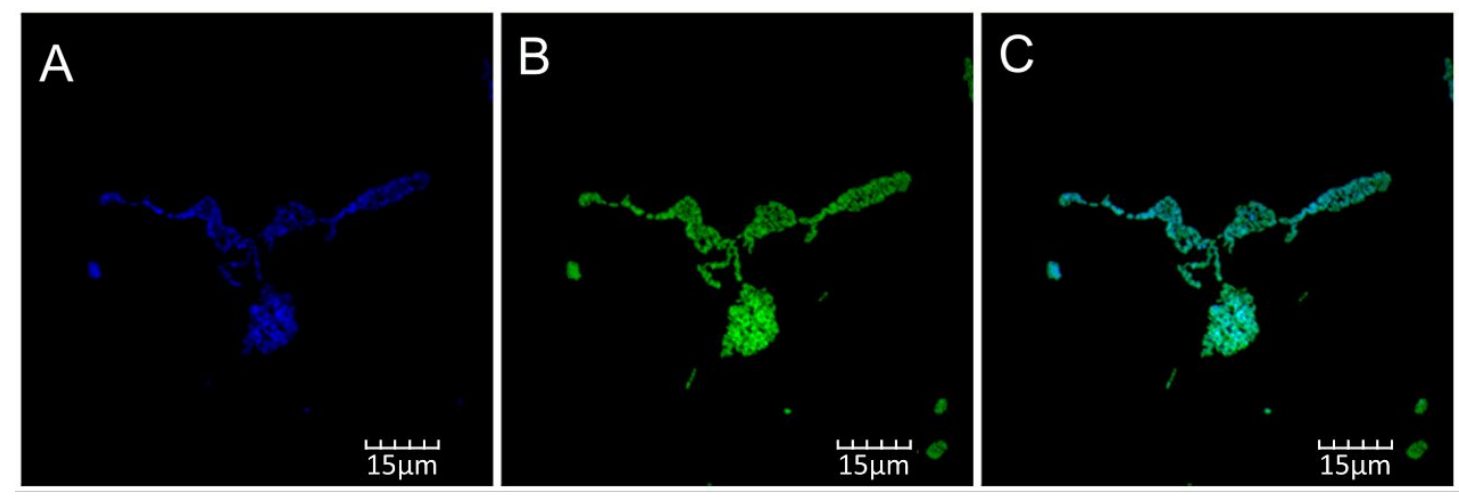

Figure S19. CLSM images of E. coli stained by FITC-OPE-4 and DAPI. The images of $E$. coli stained by DAPI and FITC, and the merged images are named by a, b and c, respectively. Scale bars are $15 \mu \mathrm{m}$.

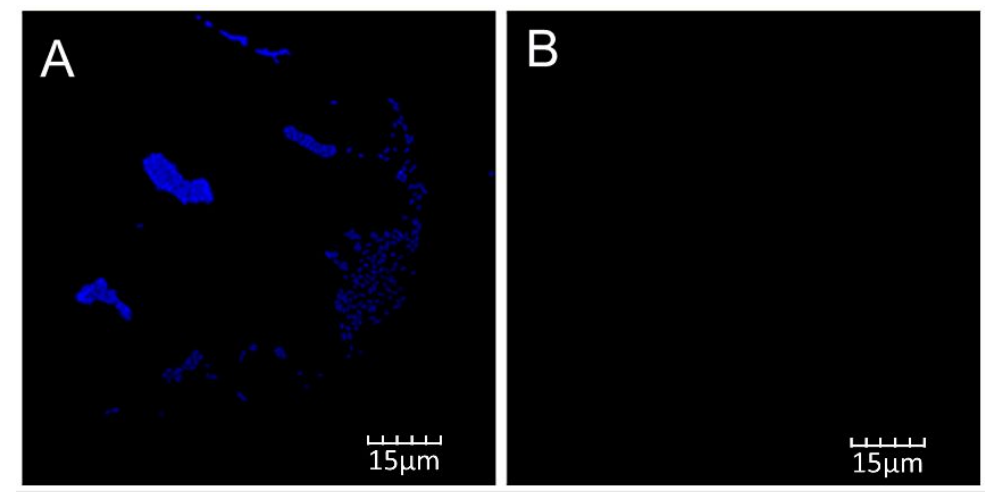


Figure S20. CLSM images of $E$. coli stained by DAPI. The images of $E$. coli staided by DAPI and FITC, are named by a and b respectively. Scale bars are $15 \mu \mathrm{m}$. 